\title{
OPIEKA NAD DZIELAMI SZTUKI W TERENIE SPRAWOWANA PRZEZ MUZEA DIECEZJALNE I PROWINCJALNE
}

„Jednym z przejawów życia Kościoła jest sztuka sakralna, wyrażająca misterium chrześcijaństwa i zwiastująca je światu. Jej dawne i współczesne dzieła stanowią «patrymonium artisticum Ecclesiae», a zarazem skarb kultury ogólnoludzkiej. Ten skarb powierzony jest opiece duchowieństwa i wiernych"'. Takim stwierdzeniem rozpoczyna się Instrukcja Episkopatu Polski o Ochronie Zabytków i Kierunkach Rozwoju Sztuki Kościelnej, wydana w roku 1966. W innym miejscu tejże instrukcji biskupi przypominają, że proboszczowie ,nie są właścicielami, lecz tylko stróżami i opiekunami dzieł sztuki sakralnej, znajdujących się w obiektach powierzonych ich pieczy. Dlatego w żadnym wypadku nie wolno im najmniejszych nawet dzieł sztuki (jak np. zniszczone obrazy, figury, tzw. świątki, lichtarze, stare księgi, zegary) przenosić do innych kościołów, zabierać ze sobą na inna placówkę, sprzedawać lub darować. Dzieła takie należy zabezpieczyć przed kradzieżą i zniszczeniem, a jeśli ich stan nie pozwala na ekspozycję w kościele, przechowywać $\mathrm{w}$ odpowiednim pomieszczeniu lub też przekazać muzeum diecezjalnemu"2.

Cytowany tu zapis instrukcji Episkopatu Polski dowodzi, że rola, jaką muzeum diecezjalne czy prowincjale odgrywa w dziedzinie opieki nad dziełami sztuki $\mathrm{w}$ terenie wydaje się być oczywistą. Z samej definicji muzeum wynikają również zadania, jakie stają do zrealizowania przez taką placówkę. Jednym z celów muzeum, określonym przez ustawę państwową jest „trwała ochrona dóbr kultury”, a cel ten realizuje poprzez ,gromadzenie dóbr kultury, katalogowanie i naukowe opracowywanie zgromadzonych muzealiów, przechowywanie gromadzonych dóbr kultury, w warunkach zapewniających im właściwy stan zachowania i bezpie-

${ }^{1}$ Instrukcja Episkopatu Polski o Ochronie Zabytków i Kierunkach Rozwoju Sztuki Kościelnej z 16 kwietnia 1966 roku, w:. Dokumenty duszpastersko-liturgiczne Episkopatu Polski 1966-1993, Lublin 1994, s. 301.

${ }^{2}$ Tamże, s. 302. 
czeństwo, oraz magazynowanie ich, w sposób dostępny dla celów naukowych, zabezpieczenie i konserwację muzealiów"3.

O roli muzeum w ochronie dóbr kultury nie zapomina również prawodawstwo kościelneprzypominającinakazującjednocześniewNormachPostępowaniawSprawach Sztuki Kościelnej wydanych w roku 1973, by „obiekty wycofane z kultu lub dekoracji wnętrza kościelnego umieścić w osobnych i zabezpieczonych pomieszczeniach, jako zaczątek kolekcji parafialnej lub klasztornej, albo oddać do muzeum diecezjalnego, a wszelkie obiekty sztuki i kultury kościelnej winny być strzeżone z największą troską i odpowiedzialnością przed Bogiem i Narodem"4.

Musimy również pamiętać, że ochrona zabytków oznacza nie tylko ich konserwację, ale również, a może przede wszystkim, wszelkie działania mające na celu zabezpieczenie ich przed zniszczeniem, uszkodzeniem, dewastacją, zaginięciem. Rozpatrując zagadnienie ochrony dzieł sztuki sakralnej znajdujących się $\mathrm{w}$ terenie a sprawowanej przez muzeum diecezjalne pamiętać też musimy i o tym, iż pośród cennych przedmiotów znajdują się nie tylko zabytki ruchome, które w koniecznych przypadkach można przenieść do muzeum i tam w odpowiedni sposób zabezpieczyć przed zniszczeniem. Muzeum diecezjalne czy prowincjalne sprawując opiekę nad zabytkami sztuki sakralnej w terenie, może realizować to zadanie nie tylko wobec przedmiotów ruchomych, które z rozmaitych względów wycofane zostały z kultu, ale również wobec zabytków architektury, to znaczy zabytkowych kościołów.

Odbywa się to poprzez działające najczęściej przy muzeach Diecezjalne Komisje do Spraw Sztuki Kościelnej, nierzadko bywa również i tak, że dyrektorem muzeum diecezjalnego jest jednocześnie przewodniczący diecezjalnej komisji do spraw sztuki kościelnej.

Opieka nad dziełami sztuki dotyczy jednak przede wszystkim ruchomych przedmiotów zabytkowych, które $\mathrm{z}$ różnych powodów zostały wycofane $\mathrm{z}$ kultu, nie znajdują już miejsca $w$ świątyniach, często przechowywane są na terenie parafii w bardzo niekorzystnych warunkach, na strychach, starych i nieogrzewanych organistówkach, niezamieszkanych starych plebaniach, lub innych miejscach, w których ulegają szybkiemu procesowi niszczenia.

W wielu kościołach cenne przedmioty narażone są nie tylko na niekorzystne działanie czasu, szkodliwe warunki atmosferyczne, ale również na pożary lub kradzieże, które w ostatnim czasie nasiliły się szczególnie w południowej Polsce. Ciągle jeszcze do rzadkości należą parafie, w których funkcjonowałby sprawnie działający system alarmowy. Niestety w wielu parafiach nie ma również jeszcze katalogów zabytków parafialnych. Na marginesie wypada dodać, iż obowiązek sporządzenia takich katalogów i przeprowadzenia dokładnej inwentaryzacji nałożyła na rządców parafii Konferencja Episkopatu Polski w roku 1973. W paragrafie 6 cytowanych już Norm Postępowania w Sprawach Sztuki Kościelnej czytamy: „Rządcy parafii i kościołów przeprowadzą inwentaryzację przedmiotów kultu

${ }^{3}$ Ustawa z dnia 21 listopada 1996 roku o muzeach, „Dziennik Ustaw”, z 20 stycznia 1997 roku, nr 5, poz. 24.

${ }^{4}$ Normy Postępowania w Sprawach Sztuki Kościelnej wydane przez Konferencję Episkopatu Polski 25 stycznia 1973 roku, w: Dokumenty, s. 317. 
i zabytków oraz wyposażeń wnętrza kościołów i kaplic, obiektów kultury wszystkich pomieszczeń sakralnych oraz kapliczek terenu parafii. Spis taki winien zawierać opis obiektów i ich fotografie. Jeden egzemplarz spisu pozostaje u rządcy kościoła lub parafii, drugi zaś będzie przekazany do archiwum Referatu do Spraw Sztuki, albo do Muzeum Diecezjalnego lub Klasztornego"s. Należałoby tu dziś zapytać, w jaki sposób zarządzenia te są realizowane i dlaczego tak powoli?

Ogromną pomocą w inwentaryzacji dzieł sztuki, znajdujących się na terenie parafii, inwentaryzacji, która jest jednym z pierwszych i podstawowych etapów w opiece nad zabytkami, mogą służyć istniejące na terenie diecezji lub prowincji muzea diecezjalne czy prowincjalne. Niekiedy księża kierowani dobrą wolą pragną zachować cenne przedmioty przed kradzieżą, i dlatego ukrywają je przed przedstawicielami państwowej służby ochrony zabytków. Większym zaufaniem darzą jednak pracowników muzeów diecezjalnych, którzy posiadając odpowiednie przygotowanie zawodowe potrafią we właściwy sposób dokonać inwentaryzacji zabytków parafialnych.

Fakt istnienia $\mathrm{w}$ diecezji muzeum daje również rządcom parafii możliwość przekazywania zabytkowych przedmiotów do takiej placówki, w której mogą być one przechowywane $\mathrm{w}$ odpowiednich warunkach, zabezpieczone przed niszczącym działaniem szkodliwych czynników biologicznych lub innych, oraz przed kradzieżą. W Muzeum Diecezjalnym w Kielcach przechowywane są przedmioty, które gromadzone były z myślą o muzeum diecezjalnym już od roku 1911. Księża z terenu całej diecezji ofiarowywali między innymi gotyckie obrazy, które ze względu na zły stan zachowania i brak środków na ich odnowienie mogłyby ulec całkowitemu zniszczeniu. Wśród przedmiotów przekazywanych do muzeów znajdują się dziś kielichy mszalne i monstrancje. Pokaźną ilość stanowią relikwiarze, często nieznanych już świętych, jednak najchętniej przekazywane są zabytkowe ornaty, które też w wielu muzeach stanowią największą część kolekcji muzealnej.

Fakt gromadzenia i przechowywania zabytkowych przedmiotów stanowi często dla niewielkiego muzeum diecezjalnego lub klasztornego poważny problem związany z brakiem odpowiedniej wielkości pomieszczeń magazynowych. Problem ten jest często przyczyną, dla której niestety nie wszystkie zabytki mogą znaleźć schronienie w muzeum.

Zdarza się, że przedmioty takie, nim trafią do muzeum w formie darowizny lub depozytu, są już bardzo zniszczone. Przy niektórych muzeach funkcjonują diecezjalne pracownie konserwatorskie. To w nich właśnie zabiegom konserwatorskim poddawane są obiekty wycofane z kultu i przekazane do muzeum.

Współpraca Muzeum Diecezjalnego w Kielcach z Wojewódzkim Konserwatorem Zabytków, z Komendą Wojewódzką Policji oraz Strażą Pożarną zaowocowało utworzeniem specjalnej grupy, złożonej z przedstawicieli wymienionych instytucji, której zadaniem jest wizytowanie wytypowanych kościołów zabytkowych i sprawdzanie stanu ich zabezpieczenia przed włamaniem lub pożarem. Wizytacje takie stanowią również doskonałą okazję do tego, by sprawdzać stan za-

\footnotetext{
${ }^{5}$ Tamże, s. 313.
} 
chowania zabytkowych przedmiotów ruchomych, ale również stan zachowania zabytków architektury. W protokołach powizytacyjnych rządcy parafii otrzymują szczegółowe i fachowe instrukcje, dotyczące działań, jakie muszą podjąć, by poprawić stan bezpieczeństwa zabytków znajdujących się na terenie parafii.

Muzea diecezjalne czy prowincjalne w ramach swych działań statutowych przygotowują wystawy czasowe, prezentujące najciekawsze zabytki z wybranych parafii, dekanatów lub inne wystawy tematyczne, na których prezentowane są zabytki, na co dzień znajdujące się w terenie. Kwerendy prowadzone w trakcie przygotowywania wystaw są doskonałą okazją do odnajdywania przedmiotów, które dotychczas nie były znane, a tym bardziej nie były umieszczone w żadnej ewidencji. Przykładem takich ciekawych znalezisk jest obraz El Greco, przechowywany i prezentowany w Muzeum Diecezjalnym w Siedlcach.

Sądzę, iż zadanie opieki nad zabytkami sztuki sakralnej muzea diecezjalne czy prowincjalne wypełniają również dzięki rozmaitym działaniom edukacyjnym. Uwrażliwianie wiernych, ale i rządców parafii na ogromną wartość kulturową, historyczną, religijną i społeczną zabytkowych przedmiotów, powoduje, iż ludzie zwracająnaniewiększąuwagę, otaczająopiekąichroniąprzedzniszczeniem, aw wielu przypadkach studzi ogromny entuzjazm w wymienianiu przedmiotów zabytkowych na nowe.

Przedstawione tu w ogromnym skrócie działania, jakie podejmują muzea diecezjalne i prowincjalne w dziedzinie opieki nad zabytkami sztuki sakralnej wydają się być wszystkim oczywiste i w muzeach prowadzone są już od wielu lat. Jednak nowe wyzwania i nowe możliwości, przede wszystkim techniczne, sprawiają, iż można wprowadzać w życie nowe projekty, mające na celu zwiększenie skuteczności w ochronie zabytków sztuki sakralnej. W czerwcu 2005 roku w Muzeum Diecezjalnym w Kielcach powstał program ochrony zabytków parafii diecezji kieleckiej. W połowie października rozpoczęło działalność Diecezjalne Centrum Monitoringu Parafii. Centrum zostało zbudowane w celu przyjmowania i obsługi sygnałów alarmowych przychodzących z odległych obiektów i powodowanie odpowiednich reakcji w sytuacjach zagrożenia. Doświadczenie uczy bowiem, iż zainstalowanie w kościele systemu alarmowego nie jest gwarantem uchronienia przed włamaniem i kradzieżą. Zdarza się i tak, iż po włączeniu alarmu, szczególnie w parafiach wiejskich, nie ma nikogo, kto mógłby podjąć odpowiednie działania. Często alarmy włączają się z nieuzasadnionych powodów i po kilku seriach takich fałszywych alarmów, cały system jest po prostu wyłączany. Diecezjalne Centrum Monitoringu w Kielcach zostało powołane w tym celu, by te wszystkie wady wyeliminować.

Centrum monitoringu obsługiwane jest całodobowo poprzez odpowiednio dobrany i wykwalifikowany personel. Zostało wyposażone w nowoczesny sprzęt bazę monitorowania alarmów. Baza ta przyjmuje sygnały nadawane przez nadajniki zainstalowane w obiektach chronionych. Sygnał przesyłany jest drogą bezprzewodową, co znacząco podnosi bezpieczeństwo i pewność jego przesłania do bazy. Linie telefoniczne narażone są na celowe lub przypadkowe uszkodzenie. Dyżurny bazy, po otrzymaniu sygnału alarmowego podejmuje działania ustalone procedurą dostosowaną do konkretnych zagrożeń. W przypadku otrzymania syg- 
nału włamania lub próby kradzieży obrazu albo zabytkowej rzeźby lub innego cennego przedmiotu, chronionego w szczególny sposób specjalnymi czujkami, dyżurny powiadamia policję, oraz ściśle określoną grupę osób przebywających w pobliżu miejsca zdarzenia lub grupę interwencyjną. W przypadku otrzymania sygnałów technicznych takich jak brak prądu, usterka lub uszkodzenie systemu alarmowego dyżurny wysyła patrol techniczny. Wszystkie działania operatora wynikają ze ściśle określonych procedur, są rejestrowane i archiwizowane. $\mathrm{Na}$ terenie parafii ochronie podlegają zarówno zabytkowe obiekty ruchome jak również kościoły, plebanie i kaplice.

Zainstalowany w parafii system oprócz włamania, napadu, pożaru, sytuacji związanej z ulatnianiem się gazu, reaguje również na próby uszkodzeń lub nawet na sytuacje związane z zagrożeniem wynikającym z zalania wodą.

Pracownicy Diecezjalnego Centrum Monitoringu w Kielcach mają możliwość instalowania w kościołach sprawdzonych systemów alarmowych, takich, by zbudowane były z odpowiednich urządzeń, w odpowiedni sposób, skuteczny i niegenerujący niepotrzebnych kosztów. Tylko wtedy bowiem system taki dobrze służy i pozwala na dobre monitorowanie. W przypadku istniejących już systemów alarmowych pracownicy muzeum kontrolują je i usuwają słabe strony.

Tak zorganizowany system ochrony zabytkach znajdujących się na terenie parafii pozwala na realne zwiększenie bezpieczeństwa nie tylko w terenie, w kościołach często położonych na uboczu, ale również zwiększa bezpieczeństwo zbiorów przechowywanych w samym muzeum diecezjalnym. Chronione jest ono bowiem nie tylko systemem alarmowym i zabezpieczeniami mechanicznymi, ale również całodobowo przez pracowników Diecezjalnego Centrum Monitoringu, pełniących jednocześnie funkcje straży muzealnej.

Wypada mieć nadzieję, iż działania, jakie podejmują muzea diecezjalne i prowincjalne w dziedzinie opieki nad zabytkami sztuki sakralnej będą nieustannie poprawiały stan bezpieczeństwa bezcennych nierzadko skarbów. Jednocześnie należy też podziękować za dotychczasowe działania, które prowadzone często w skromnych warunkach i przy użyciu niewielkich środków w tak znaczący sposób przyczyniają się do zachowania przed zniszczeniem ogromnego dziedzictwa polskiej sztuki sakralnej. 